\title{
Non-Henrian partitioning of nitrogen in slab environments
}

\author{
COLIN R.M. JACKSON ${ }^{1 *}$, ELIZABETH COTTRELL ${ }^{2}$
}

${ }^{1}$ Tulane University, New Orleans, LA, USA

(*correspondence: jackson2@tulane.edu)

${ }^{2} \mathrm{NMNH}$, Smithsonian, Washington, DC, USA

Nitrogen is transported into subduction zones in sediments and the uppermost oceanic crust. Because $\mathrm{NH}_{4}{ }^{+}$is compatible in slab minerals, while $\mathrm{NH}_{3}$ and $\mathrm{N}_{2}$ are less so, the ability of $\mathrm{N}$ to be retained in the slab during dehydration and melting depends on the relative stability of $\mathrm{N}$ species as a function of $\mathrm{P}, \mathrm{T}, f \mathrm{O}_{2}$, and $\mathrm{pH}$. These dependencies make $\mathrm{N}$ an information-rich tracer of slab conditions, but the relative stability of $\mathrm{N}$ species is also predicted to be a function the total $\mathrm{N}$ concentration, given the stoichiometry of converting $\mathrm{NH}_{4}{ }^{+}$or $\mathrm{NH}_{3}$ to $\mathrm{N}_{2}$. Nitrogen partitioning in slab environments may therefore be non-Henrian.

Confirming the prediction of non-Henrian behavior is crucial because 1) experiments documenting the reactivity of $\mathrm{N}$ in slab settings are uniformly run at high concentrations and 2) the natural concentration of $\mathrm{N}$ in slab settings is likely highly variable, but generally much lower.

We have conducted $\mathrm{N}$ partitioning experiments under slab conditions to test for non-Henrian behavior. We completed a series of fixed pressure $(1.75 \mathrm{GPa})$ and temperature $\left(800{ }^{\circ} \mathrm{C}\right)$ piston cylinder experiments (Tulane University) using a double-capsule approach to buffer $f_{2}$ (NNO). Within the series, we reacted rhyolitic melt, biotite, and a hydrous fluid with various concentrations of $\mathrm{N}(0.4-0.25$ mole fraction $\mathrm{N})$. Experiments were analyzed by an electron microprobe (Smithsonian Institution).

Our results reveal that $\mathrm{N}$ partitioning between melt and fluid systematically decreases with increasing $\mathrm{N}$ concentration. This result is consistent with the nonHenrian behavior predicted by conversion between $\mathrm{NH}_{4}{ }^{+}$or $\mathrm{NH}_{3}$ to $\mathrm{N}_{2}$. Application of our results to nature implies an expanded stability of $\mathrm{NH}_{4}^{+}$or $\mathrm{NH}_{3}$ relative to $\mathrm{N}_{2}$. To maintain the strong enrichment of $\mathrm{N}$ at Earth's surface, despite its continuous subduction, we suggest that oxidizing, and potentially high $\mathrm{pH}$ conditions, have prevailed during dehydration of the uppermost sections of slabs through time. 